Utah State University

DigitalCommons@USU

$5-1948$

\title{
The Effect of Light, Soil Temperature, and Soil Moisture on High- Lime Chlorosis
}

Lauren M. Burtch

Utah State University

Follow this and additional works at: https://digitalcommons.usu.edu/etd

Part of the Soil Science Commons

\section{Recommended Citation}

Burtch, Lauren M., "The Effect of Light, Soil Temperature, and Soil Moisture on High-Lime Chlorosis" (1948). All Graduate Theses and Dissertations. 3951.

https://digitalcommons.usu.edu/etd/3951

This Thesis is brought to you for free and open access by the Graduate Studies at DigitalCommons@USU. It has been accepted for inclusion in All Graduate Theses and Dissertations by an authorized administrator of DigitalCommons@USU.For more information, please contact digitalcommons@usu.edu.

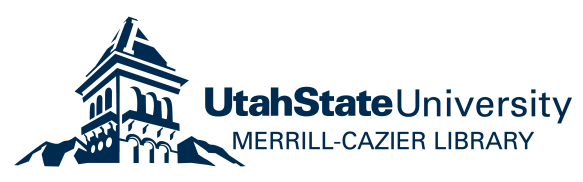


THE BFPBCT OP LTOET, SOTL REMPSRATURE, AWD SOTL HoTsTuE ON HIOH-LIME CHLOROSIS

by

Lauren M. Burtoh

A thesis subultted in partial fulfillment of the requirenents for the degree

of

MASTBR OF SCTENCE

in

Soll Salenee

1948

WAH STATE AGRTCULTURAL COLLEG

Logan, Vtah 


\section{ACKNOAL, SDOEMSNT}

The writer expresses sincere eppreolation to Dr. D. W. Thorne, head of the Agronomy Departaent, for suggestions In planning and exeeuting the experimental woric and for enoouragement and guidanse throughout the investigation. Sincere thanks are also expressed to Dr. F. B. Tann of the Botany Department, for the use of equipment and epace in the Botany greonhouse and for his helpful suggestion in planning the experiments, The writer partioularly acknowledges the ald of his wife for help with the ehemieal analyses and for preparing the diagrams and graphs used in the text of the thesis. 
TABLB OP COMTRETS

Page

Introduotioa ....................... 1

Review of LAteraturs ................. 5

Hght ...................... 8

Temperature ................... 4

Noisture ................. 5

General Prosedure .................. 8

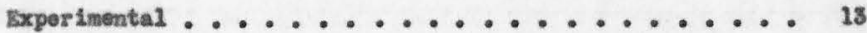

Experiment I.................. 13

Experimont II.................. 19

Experimont III ................. 26

Experiment IV .................. 34

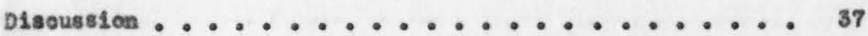

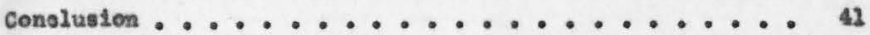

Sumary ...................... 48

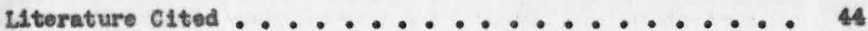




\section{INTROD UCTION}

Chlorosis of plants from lack of avalable iron is one of the most sosmon plant nutrient problems of the alaareous solls of the west. The disease is eharasterised by a yellowing of the plant leaves and is aosompanied, in severe ases, by a partial root death and premature defoliation (3). In addition to redualng growth, the disease greatly reduees the quality and yield of plants.

Many types of plants are affeated by iron ahlorosis. In Hawai1 and Porto R100 rise, बugar ane and plnespple are susaeptible, while in Californie and Arisona, oltrus trees are seriously affected. In Utah apples, peaches, plums, prunes, aprieots, pears, grapes, raspberries and maxy ormamental plants are affeoted (27). The problem of Iron ohlorosis, therefore, is of great Importance to agrioulture in the west.

Chloresis has been studied for more than one hundred and fifty years, but until reoently, little progress has been made toward findIng the solution to the problem. Although these past studies have not solved the problem of iron ohloresis, they have shown many faotors to be elosely related to the osourrenee of the disease.

These factors include an unbalanesd ratio of avallable manganese to Iron in the growth medlum $(9,23,28)$; ohlorotis leaves are high In potessiun, nitrogen in the form of amonia (21), and in ferrio Iron and are $10 \mathrm{w}$ in total oulolusi and ferrous iron in comparison with green 1eaves (12, 13, 14, 17, 25, 26). 
The olimatio factors of 11ght, sell tenperature and soll moleture also appear to be of fundemental impertance in ohlorosis. It 16 a comon observation that fruit trees are more ohlorotio during the early spring when the temperature of the soll is low and the molsm ture level high. Many Investigators have noted that ohlorosis tends to be nost severe in the poorly dreined portions of fruit orohards when water tends to avounulate. However, the work on the effeot of olimatio oonditions on shiorosis has been IImited largely to observet1one.

The purpose of this Investigation was to study, under oontrelled oond1tions, the effeot of 11ght, soll temperature and soll moisture on a 11me-induaed ohloresls. 


\section{REVTEW OF LTFERATUES}

Beosuse of the extensive literature on the subject of ahlorosis, it is felt that the presentation of complete 11terature review is. not advisable. The review of 11terature will be 1 imited, thereforag to the factors directly asnneated with this research, namely, 11ght, so11 tempersture and sol1 molsture.

Light

Gerleke (5), in 1925, observed that the defielency or absence of Iron hod a more harnful effeot on plante growing in bright sunlight than It had on those growling under shaded conditions. From this observation, he eovioluded that the plant's noed for Iron Inoreases with the plant's exposure to 1ight. Gerloke thought that this Inareased nod for 1 ron was due to a more rapid rate of growth in the $11 \mathrm{ght} /$ for although the plants exposed to bright sualight were muoh waller then those grown in the shade, they were more mature.

Irgalls and shive (10) found that the pll inareased in the flusd extracts of stems and leaves during the day and deareased at night. They observed that plente having relatively low pll values for tissuo Pluids absorbed very amall quantities of lron, but the abserbed 1ron under oonditiens of low pll remained soluble and henoe presumably was availeble for ohlorophyll formation. In speoles having the pll of t1ssw flulds near ar above the preaipltation point of iron, Iron tended to acounulate in the tieaves in an insoluble form and as sush sould not be used in the synthesis of ohlorophyly. One Interrelationship between 21ght and ohlorosis, therefore, would appear to be 
as follows the pll of the plant tissue fluids inorease as the 11ght 1atensity increases. W1th the inorease in pll, Iron preaipitates in the plant tiseues and besones umavaliable, and shloresls develops as a result of a defleienoy of iron.

In addition to affeoting the pll of the plant tistue fluids, Iight seans to play an important role in the oxidation-reduction system of the plant. Hopkins and others (\$) found that solutlons of Iron in the form of ferris oltrate were reduoed to the ferrous form by sunlight. The effert of 1ight in this reduotion aems to be a catalytio one, and Hopicins coneludes that the state of oxidation of iron is not sonstant but variable with 1 ight Intensity, permeablilty of leaf t1sanes to 11ght, the anount of manganese, the peraeability of the tissues to oxygen and oarbon dioxide and the rate of photosynthesis and respiration. Although the problem is very somplex beosuse of the number of unprediotable faotors, Hopicins (9) belleves that, "Light is of great importanee In Influenelng the effeot of Iron and manganese on plant growth, and that 1 ts maln role oonsiste of its sontrel of the oxidation potential." Texperature

At the prosent time 11ttle Information is avaliable soncerning the Influence of temperature on ahlorosis. It has, however, long been ommen knowledge that ohlorosis is often most serere in the early spring. especially arter a sudden temperature deorease. Jones (11) not1ood that the leaves of gardenia plants growing in the greenhouse in winter beasme ahlorotio when the gardenis pots were placed in the cooler seotion of the greenhouse. When these ahlerotis gardenlas were plaoed noar the steam pipes, the leaves soen regained their heslthy green soler. Further 
Investigations by Jones showed that the temperature of the soll is a definite factor In Indueing ahlorosid.

Chlorosis seems to eoour under high soll temperatures as well as under low soll temperatures. Wann (27) found that chlorosis of grapes wse nost severe during the mideukmer period of high 1 Lght intensity and high temperatures. The explanation that usually asoompanles this observation is that the high temperature exidises soluble ferrous iron In the soll to the ferrie form whioh is prealpitated In the sell as hydrated Porrie oxide. Iron thus beomes unavailable to the plant, and ohlores is results from iron deflalenoy.

Hofler (8) reports that acoording to observations in Austria, humd springs, followed by sudden sumber hest are fastor in the development of ahlorosis on the high-12me solis of that rogion. Hofler altes the observations of other Corman and Austrian solentiste that abnormally oold perlods early in the year followed by normal or excessively warm temperstures produse a mgriced chlorosis of plant leaves.

\section{Mol sture}

The influence of molsture and aeration on Iron avallabllity is another phase of ohlorosis about whloh little is knom. Haas (7) observed that on aalcareous s011s the most vigorous trees were found on soll In which the molsture equivalent values elther deoreased or renained relatively unohanged with ineressing depth. Under these oonditions the pll of the soll was lower, and the soll aeration was improved. Q1le and Carroro (6) roported that the avallability of 1ron in ealeareous solls was sl1ghtly greater near the optimum molsture sontent of the so11 than et higher water levels, but it remalned for Burgess and Pohlman (2) in Arizona to show that the method of irrigation 1s associated with 
ehlores1s. They were able to show that the oonason prat1se on irrigated land of malntaining soli nolsture alose to the field oapaolty level much of the time is one of the prinolpal sases of ohloresis. The se Ar1zona Investigators denonstrated that by permitting the soll to approseh the witing point before Irrigation and then applying a heavy Irrigation of five or ix inohes of water, the ahlorotio condition sould be markediy reduoed. In splte of the faot that this work has been duplisated by others, there 1: much oontroversy over the reason for the resulte obtainad. The prinolpal benefits from this controllad irrigation were attributed to the ingrovement of soll aeration and pronotion of a more favorable pH, Nost Investigators are in agreenent that the lowerIng of the exygen pressure of the sol1 promotes the reduation of ferrio iron to ferrous and Inorasses soll alkalinity. On the other hand, inoreasing the oxycen preseure oreates acroblo oonditlons whi oh tond to oxidize ferrous iron to ferrie iron. However, these aerobis oonditions tend to reduae soll pH, and 011 in all sond1t1ons for plant growth are greatly improved.

Reuther and Oramford (19) observed that in sumer pratioally no ohlorosis oovurred on any plots regardless of nolsture treataents, but that during the winter months and early epring, ohlorosis incrsased markedly on the wet plots and only sllghtly on the normel molsture plots. Mowever, the trees grown on wet plots made more grosth and had larger leaves and more dry weight than the trees grown on the Ary plots. Further invest1gatlons by leuther and Crawiord (20) showed that ohlore51. was wost severe in the winter when the oxygen consentration was highost. They also noted that over-irrigation inoreased ohiorosis. 
From their studies they ooneluded that, "There is an Inverse relation between the meisture content of Irrigated saloareous soils and the concentration of oxygen in the soll atmosphere, and a direot relation to the carbon dioxide ooneentration." From their work and the findinge of Whitney and Gardner (28) they suggest that the hypothesis that a alcareous soll besomes more alkaline as the molsture content is inoreased may not be true and should be studied further. 
The general prosedure was to grow bean plants in a high-lime soll placed in deep pots submerged in water baths themostationly oontrelied at desired temperatures. Frovisiens were also mede for regulatins 11ght conditions on the plants and moisture avallability in tho soli. Blagram 1 showe the experisental design used in the grsenherse experinents. The design of the eutdoor experisent is showa in diegran 2.

The soll seleated was a highly ouloareous sell in whloh a wide varlety of plants besane ahlorotis. The soll was fros the site of ohloresti fleld studies loosted esst of Fifth Bast Street in Logan, Utah, between Seventh and sighth Jorth streets. The sel2 w was brought in molst from the field, nixed, fertilised with 16-20 0 rertiliser and placed in 15-inoh deep Iron pots. These pots hed previously been treated with Ilodaiceat paint. Care was telcen to prevent the soll fron drying during the potting operations.

Each water bath was thernostatially oontrolled and saintained with In approximatedy $+2^{\circ} \mathrm{C}$. of the experinental temperature. Terperatrures were seleoted at various points ever the range of 14 to $36^{\circ} \mathrm{C}$.

- The soll desoription was as Follews: Cac0s, 38/, molnture equivilent, $29 \%$ pll. 7.8 ; organis watter, $4.7,4$ read1ly svaliable potassíw, 425

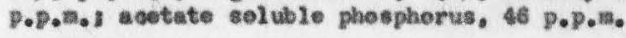

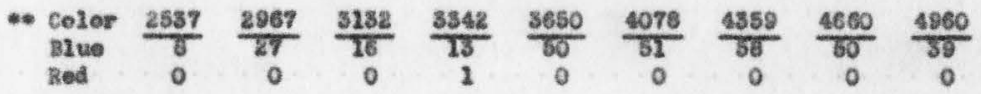

Celer $\frac{546 \lambda}{15} \quad \frac{5750}{5.5} \quad \frac{6234}{0} \quad \frac{6500}{0} \quad \frac{6900}{25}$

fled $0 \quad 6.5 \quad 76 \quad 80 \quad 37$

Fisible Light liays - 4078 - 6900

vitravielet Light liays - Belor 4078 


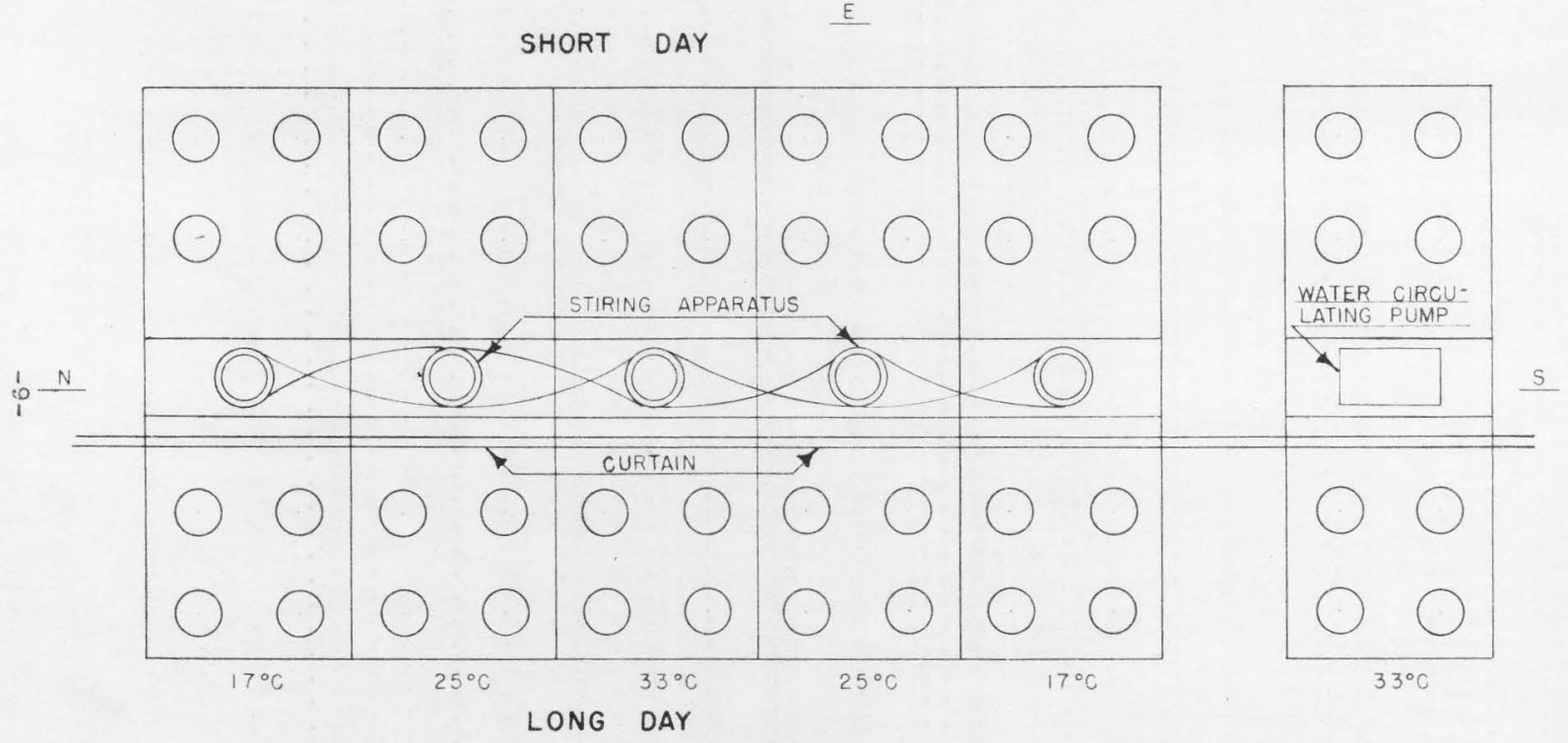

DIAGRAM 1. ARRANGEMENT OF CONSTANT TEMPERATURE BATHS, POTS AND LIGHT TREATMENTS IN THE GREENHOUSE . 
E

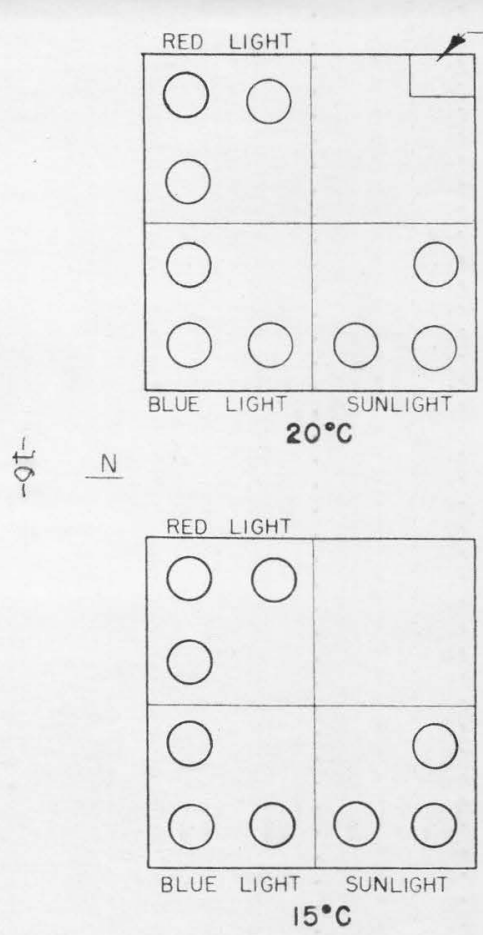

WATER CIRCULATING PUMPS
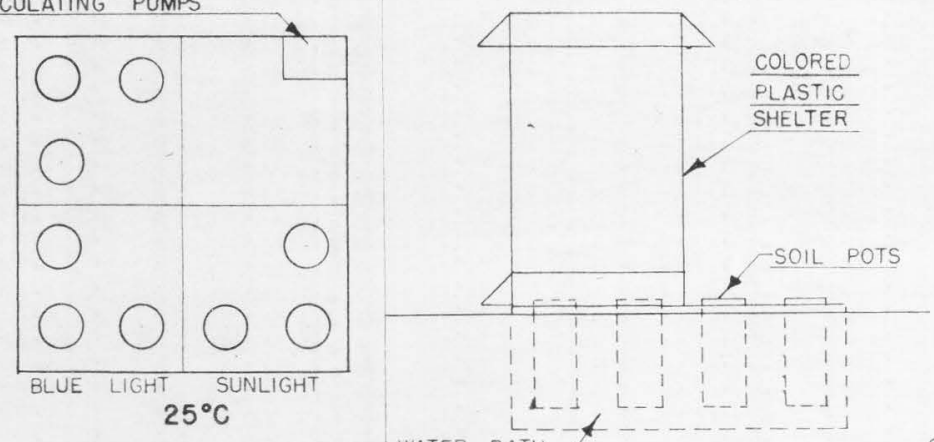

WATER BATH
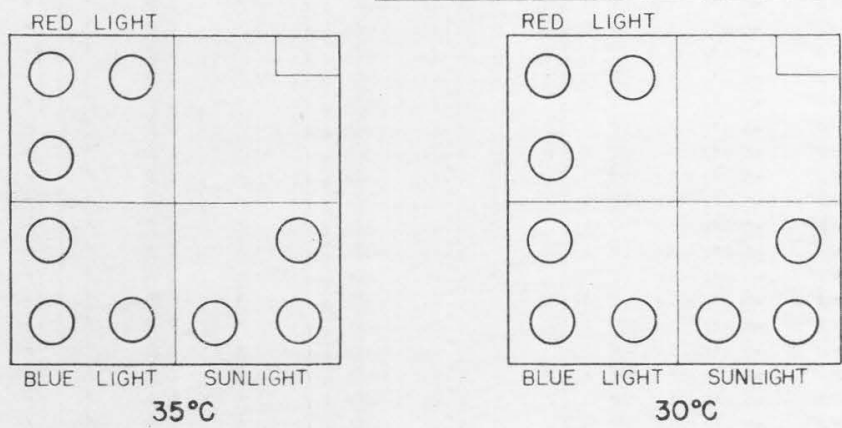

DIAGRAM 2. ARRANGEMENT OF CONSTANT TEMPERATURE BATHS, POTS AND LIGHT TREATMENTS IN THE OUTDOOR EXPERIMENT. 
The higher teaperatured baths were heated by glass eneased heaters, somposed of 25 feet of colled ehrome wire of .664 ohms per foot resise tance. The water in the baths was agitated by elestric punps in the heated tanks and by a steady flow of coollng water in the unheated tanks, The water baths in the greenhouse were stirred by means of oteel paddles, powered by en eleotric motor and a system of pulleys.

Bean plants of the Oreat Northern variety were used as test plents. The seeds were gerainated in peat moss and then transplanted to the sol1 in the potg-orive plants being left in eash pot.

Different 11 ght and molsture oonditions were provided for the plants in each bath. The 11ght oonditions empleyed in the greenheuse inoluded norms daylight and normel daylight plus 7 hours of artifloial 111 undnation. The 1ight oonditions employed in the outalde experiments insluded full sumer sunlight, and sunllght through red and blue plastios of known 11 ght transmdssion values, the colored, reenforoed plastie material was mede by the Dobealcum Company of Cleveland, Ohie.

Soll molsture in the greenhouse experiments was ontrolled through the use of soil tensiometers and Bowyoupos blooks. In the outdoor experiments nolsture was oentrolled by welghing the pots at frequent intervals. The molsture levels used in the greenhouse inoluded irrigation with maximus so11 molwture tensiens of $75,100,250,600-700$ sentineters of water and near the wilting polnt.

Observations on degree of growth and ohloresis of the plants were made at weekly intervals. Upon the sompletion of each experiment, the plant tops were harvested, and the stem length and terminal loaf meas- 
urements were resorded. The leaves were then separated fron the stems, and both stems and leaves were washed in .01 $\mathrm{w}$ HCL and dist11led water. The tops were dried in a drying oven for $48-72$ hours at $65-75^{\circ} \mathrm{F}$. After the diry weights were recorded, the plant material was ground in poreeIain nortar and pestle. Separate chemleal analyses were then oonduoted on leaves, steas and, In one sase, roots. Iwo-gram samples of ground plant material were digeated with a one to one nitrio-perohlorio acld rixture, evaporated unt1 colorless and diluted to final volune of 200 os. Fron these basio solutions allquot: were taken and analyzed colorimetrioally for the following: manganese by the periodate method $(4)$ s phosphorus by the reduotion of phosphomeiybdate with andel aesording to the prosedure of Allen (1): potassium and oaleiun by the prosedure reported by feitemeyer (18), Iron by the 1-10 orthophenanthrolene prosedure as disoussed by Smith (22). An A. C. Fisher type oolorimeter was ueed for the deterninations. 


\section{EXPERTEESAL}

Bxperiment 1

In January of 1947, a prel1minary Ereenhouse experiment was undertaken to study the Influenge of sol1 temperature ad 11 ght duration on the growth and ohlorosis of beans.

F1Fe sonerete taxics leated In the botany greenhouse were wired with heatere and thernoatats. The five tanks were divided in half by a black ourtain, whioh prevented any 11ght trinsaission. Imacdiately above osh tank and on the west $81 d$, a 500 watt bulb was mounted to provide extra 111unination. Elght soll pots were plaoed in eash bath, four pots realving noral winter daylight with the other four pots reodving nornal winter daylight plus 7 hours of extra 11lualnat1on. The temperatures used were as follows: $25,20,25,50$ and 35 degrees Ceatlgrade.

The heaters and stirring apparatus wore started sevoral days prier to the ectual planting of the bean plants in order to porait the soll In the pots to adjust to the designated temperature. On January 26. bean seedlings were planted in the soll pota, four plants to each pot. and on January 22 the 11 ght variable was 1 introduced. The plants were watered as needed wth tap water.

Obervatiene were firct reaorded on Fobruary 1. The plante reoelving edditsonel 11ght were making the most rapld grovth and in general were 11 ghter in soler than the plants reoelving less ilght. arowth appeared greatest in the 25 and 30 degree tanks followed by the 35,20 and 15 degree tanks in that order. Chlorosis was most notioublo in the 35 dogree pote. 
On February 21 the plants were harvested, and PInsl observatlons were taken. The plant tops were then washed and dried aosording to the previously deseribod prosedure. The roots were removed froal the soil, washod and dried in the oven. The average values for plant chlerosis, dry welght of tops and roote, wre shown in table 1.

At the time of harvest, the 35 degree plants were the most ohloret10, followed by the 30, the 16, 20 and 25 degree plantw. There was no aignifiant differenoe between the length of day and the degree of ohloresis for any temperature.

The plant: grown in inoreased 1ight produced oonsiderably more dry welght thas the plants reeeiving only wermal winter daylight. The greatest dry weight was produned In the internediate temperstures, and Erowth was greatly rodused in both temperature extremes (table 1). The effect of length of day and temperature on the dry welght of bean tops Is thown graphically in flgure 1.

The root weighte followed the same general trend in the Inoreased Iight, but under normal winter daylight, the most extensive root system was produced under the lowest temperatures and the most redueed root systen under the highest temperature (figure 2). There was a possibility, hovever, that some roots may have been lost during the harvest.

A separate ohemioal analysis was sondueted on the plant tops and roots for total iron, phosphorus, manganese, oalolua and potassium. The averages for the results obtained are given in table 2 . The total Iron content of the bean plante could not be correlated with the degree of ehlorosis nor with temperature. The analysis $\mathrm{dL}^{\mathrm{d}}$ 
Tablo 1. Relationships between soll temperature and 11 ght, and the growth and degree of oh3orosis of bean plants

\begin{tabular}{|c|c|c|c|}
\hline Treatment & $\begin{array}{c}\text { Chlorosis } \\
\text { rating }\end{array}$ & $\begin{array}{l}\text { Av. dry } \\
\text { weight } \\
\text { bean tope }\end{array}$ & $\begin{array}{c}\text { Av. dry } \\
\text { we Ight } \\
\text { bean roots }\end{array}$ \\
\hline & & gns. & gms. \\
\hline $\begin{array}{l}\text { Sol1 } 16^{\circ} \mathrm{C} \\
\text { Short day } \\
\text { Long day }\end{array}$ & $\begin{array}{l}1.5 \\
0.8\end{array}$ & $\begin{array}{l}2.97 \\
5.96\end{array}$ & $\begin{array}{l}0.714 \\
0.808\end{array}$ \\
\hline $\begin{array}{l}501220^{\circ} \mathrm{C} \\
\text { Short day } \\
\text { Long day }\end{array}$ & $\begin{array}{l}1.6 \\
1.3\end{array}$ & $\begin{array}{l}4.08 \\
6.87\end{array}$ & $\begin{array}{l}0.584 \\
1.187\end{array}$ \\
\hline $\begin{array}{l}\text { So11 } 25^{\circ} \mathrm{c} \\
\text { Short day } \\
\text { Long day }\end{array}$ & $\begin{array}{l}0.9 \\
0.9\end{array}$ & $\begin{array}{l}5.15 \\
8.42\end{array}$ & $\begin{array}{l}0.547 \\
2.225\end{array}$ \\
\hline $\begin{array}{l}\text { Sol1 } 30^{\circ} \mathrm{C} \\
\text { Short day } \\
\text { Long day }\end{array}$ & $\begin{array}{l}1.9 \\
1.0\end{array}$ & $\begin{array}{l}4.42 \\
7.42\end{array}$ & $\begin{array}{l}0.504 \\
0.998\end{array}$ \\
\hline $\begin{array}{l}\text { So11 } 35^{\circ} \mathrm{C} \\
\text { Short day } \\
\text { Leng day }\end{array}$ & $\begin{array}{l}3.5 \\
3.1\end{array}$ & $\begin{array}{l}3.5 E \\
3.46\end{array}$ & $\begin{array}{l}0.282 \\
0.562\end{array}$ \\
\hline
\end{tabular}

* O Indiates no ahlorosis; 1. slight yellowing; 2. general yellowing of leaves; 3 . leaves bright yellow color; 4 . leaves bright yellow with some neorosis. 


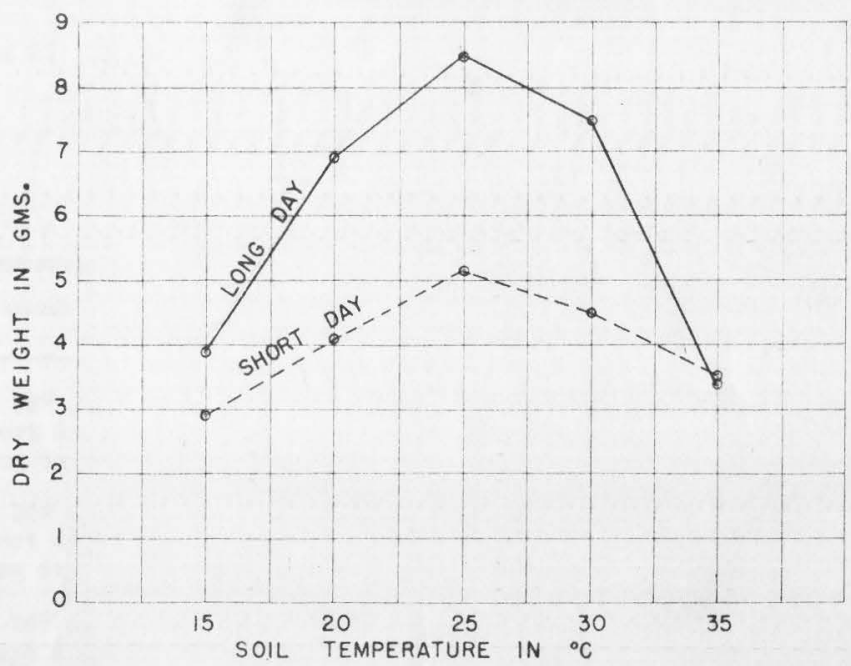

FIGURE-T. LIGHT AND SOIL TEMPERATURE IN RELATION TO DRY WEIGHT OF BEAN TOPS

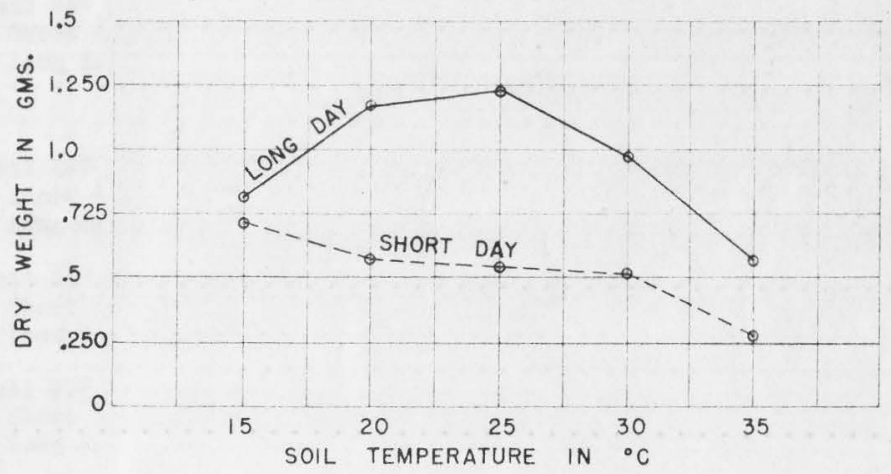

FIGURE-Z. LIGHT AND SOIL TEMPERATURE IN RELATION TO DRY WEIGHT OF BEAN ROOTS 
Table 2. The 1ron, nanganese, phosphorus, soloium and potassium content of bean tops and roots as roleted to ilght and temperature

(analyses are reported on a dry weight basis)

Bean tops

\begin{tabular}{|c|c|c|c|c|c|c|}
\hline Treatruent & $\begin{array}{l}\text { Chloresis } \\
\text { rating }\end{array}$ & Pe & $\mathrm{Man}$ & $P$ & $\mathrm{Ca}$ & $\mathbf{K}$ \\
\hline Sol1 $15^{\circ} \mathrm{C}$ & & 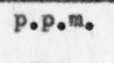 & $p_{\bullet} p_{\bullet} m_{\bullet}$ & 6 & 7 & 8 \\
\hline $\begin{array}{l}\text { Short day } \\
\text { Lone day }\end{array}$ & $\begin{array}{l}1.5 \\
0.8\end{array}$ & $\begin{array}{l}639 \\
215\end{array}$ & $\begin{array}{l}71.5 \\
69.7\end{array}$ & $\begin{array}{l}0.22 \\
0.23\end{array}$ & $\begin{array}{l}2.08 \\
2.20\end{array}$ & $\begin{array}{l}5.15 \\
6.75\end{array}$ \\
\hline $\begin{array}{l}\text { Soil } 20^{\circ} \mathrm{C} \\
\text { Short dey } \\
\text { Long day }\end{array}$ & $\begin{array}{l}1.5 \\
1.3\end{array}$ & $\begin{array}{l}232 \\
207\end{array}$ & $\begin{array}{l}68.6 \\
72.3\end{array}$ & $\begin{array}{l}0.29 \\
0.27\end{array}$ & $\begin{array}{l}2.61 \\
2.06\end{array}$ & $\begin{array}{l}5.99 \\
6.16\end{array}$ \\
\hline $\begin{array}{l}\text { Soll } 25^{\circ} \mathrm{c} \\
\text { Short day } \\
\text { long dey }\end{array}$ & $\begin{array}{l}0.9 \\
0.9\end{array}$ & $\begin{array}{l}375 \\
222\end{array}$ & $\begin{array}{l}74.6 \\
82.0\end{array}$ & $\begin{array}{l}0.28 \\
0.30\end{array}$ & $\begin{array}{l}2.35 \\
2.47\end{array}$ & $\begin{array}{l}6.72 \\
6.97\end{array}$ \\
\hline $\begin{array}{l}\text { Sol1 } 30^{\circ} \mathrm{c} \\
\text { Short day } \\
\text { Long day }\end{array}$ & $\begin{array}{l}1.9 \\
1.0\end{array}$ & $\begin{array}{l}387 \\
214\end{array}$ & $\begin{array}{l}69.1 \\
69.8\end{array}$ & $\begin{array}{l}0.32 \\
0.29\end{array}$ & $\begin{array}{l}2.39 \\
2.23\end{array}$ & $\begin{array}{l}5.84 \\
5.79\end{array}$ \\
\hline $\begin{array}{l}\text { Soil } 35^{\circ} \mathrm{C} \\
\text { Short day } \\
\text { Long day }\end{array}$ & $\begin{array}{l}3.5 \\
3.1\end{array}$ & $\begin{array}{l}613 \\
283\end{array}$ & $\begin{array}{l}60.0 \\
63.3\end{array}$ & $\begin{array}{l}0.29 \\
0.26\end{array}$ & $\begin{array}{l}2.65 \\
2.65\end{array}$ & $\begin{array}{l}6.20 \\
6.20\end{array}$ \\
\hline & & Bean ro & & & & \\
\hline $\begin{array}{l}\text { Sol1 } 15^{\circ} \mathrm{c} \\
\text { Short day } \\
\text { Long dey }\end{array}$ & $\begin{array}{l}1.5 \\
0.8\end{array}$ & $\begin{array}{l}2484 \\
2260\end{array}$ & 0.13 & $\begin{array}{l}0.16 \\
0.14\end{array}$ & $\begin{array}{l}1.61 \\
1.19\end{array}$ & 1.74 \\
\hline $\begin{array}{l}\text { Soll } 20^{\circ} \mathrm{c} \\
\text { Shert day } \\
\text { Long day }\end{array}$ & $\begin{array}{l}1.5 \\
1.3\end{array}$ & $\begin{array}{l}2968 \\
1748\end{array}$ & & $\begin{array}{l}0.19 \\
0.15\end{array}$ & $\begin{array}{l}1.50 \\
2.28\end{array}$ & $\begin{array}{l}0.52 \\
0.81\end{array}$ \\
\hline $\begin{array}{l}\text { Soll } 25^{\circ} \mathrm{C} \\
\text { Short dey } \\
\text { Long day }\end{array}$ & $\begin{array}{l}0.9 \\
0.9\end{array}$ & $\begin{array}{l}1395 \\
1908\end{array}$ & & $\begin{array}{l}0.16 \\
0.14\end{array}$ & $\begin{array}{l}1.48 \\
2.09\end{array}$ & $\begin{array}{l}1.38 \\
0.78\end{array}$ \\
\hline $\begin{array}{l}\text { Soll } 80^{\circ} \mathrm{c} \\
\text { Short day } \\
\text { Long day }\end{array}$ & $\begin{array}{l}1.9 \\
1.0\end{array}$ & $\begin{array}{l}2358 \\
3198\end{array}$ & & $\begin{array}{l}0.19 \\
0.18\end{array}$ & $\begin{array}{l}1.65 \\
1.67\end{array}$ & $\ldots$ \\
\hline $\begin{array}{l}\text { So11 } 35^{\circ} \mathrm{C} \\
\text { Short day } \\
\text { Long day }\end{array}$ & $\begin{array}{l}3.5 \\
3.1\end{array}$ & $\begin{array}{l}1935 \\
2350\end{array}$ & & $\begin{array}{l}0.13 \\
0.17\end{array}$ & $\begin{array}{l}1.50 \\
1.42\end{array}$ & $\infty$ \\
\hline
\end{tabular}


show, hewever, an extremely large iron ascuralation in the roots of the plants. The Iron sontent of roots was from 4 to 10 times greater than the Iron content of the tops.

The phosphorus sontent of the plants showed a more consistent relationship with all treatrents sontaining approximately the same content of phosphorus. This amount seemed more than adequate for optimum growth therefore, any variations in yield were in all probability not oaused by a lack of phosphorus.

The oaloium sontent of both topa and roots varled 11ttlo with either changes of temperature or 11ght. The potassium content in the bean plents varled oonsiderably with temperature, with the warimum aocumulation oosurring in the 25 degree temperature in tops and the 30 degree temperature in the roots. These results, however, did not follow any regular pattern and there was no indieation of the high potassium to caloium ratio often reported in ohlorotio leaves. These results do not disprove the existance of suoh a ratio Inasmuoh as the analysis was based on the whole plant and therefore inoluded both ohlorotle and normal tissue.

Taken as a whole, the data did not show any sonsistant differense between the length of day and the nutrient uptake of bean plants, nor did differenses of tenperature seet to influense the ontent of plant nutrisnts. In general the rcots were lower in salolun, potassiun and phosphorous than the tops, but the roots oontained anch more total Iron than the tops (table 2). 


\section{Experimont 11.}

In the summer of $\mathbf{2 9 4 7}$ a study involving the effeet of soll temperature, 11ght 1ntensity and 11ght quality on high-11an ohlorosis wes undertakn. Five oonorete tanks, loouted north of the egronony greenhouses, were wred for heaters and solenold valves to sontrol temperature. The water was agltated by eleotrio pumps in the hoated baths and by a eanstant flow of cold water in the unheated baths.

Baoh bath was divided Into three parts to provide Alfferent light sondltions. The south seotion was left exposed to the full rays of sunl1ght. Above the northeastern seotion of each tank a blue plast1s shelter was ereoted, and above the northwestern seotion of eaoh tanis a red plast10 shelter was oonetruoted. These sholters were $21 / 2$ by $21 / 2$ by 4 feot and were vent1lated at the top and bottom by a slanted opening. These openings wore construoted so that direot sun rays oould not be repleoted Inside the shelters. The red and blue aholters were separated by a layer of the red and blue saterial whioh prevented any apprealablo passage of light from one shelter to the other.

Three deep pots oontaining the high-lime soll were suspended in the water bath under each 11 ght treatment. The same temperatures that were used in the greenhouse were employed in the outdoor treatrent. These temperatures were $15,20,25,30$ and 85 degrees eentigrade.

Sinoe possibility existed that some of the chlorosis observed in the greenhouse experinent was aused by excessive moleture, noisture was controlled as acourately as possible by weighing the pots at weelcly Intervals. Solls were brought to Ileld oapasity onoe a week, and small quantities of water were added as needed botween these periods. 
On August 9, the soll was brought in from the field, mixed and Pert111zed and potted August 11. The temperature oontrols were started on August 12. On August 15, 7 bean seedlings were planted in each of the 45 pota, and on August 20 the stirring apparatus was started. The plastlo shelters ware Instalied on August 29.

Observat1ons resorded on geptember 6 Ind leated that growth wss most rapid in the red 1ight, Intermediate in the blue 11 ght and lesst rapld In full sunlipht. Only the 15 alegree plants showed any mariked ohlorosis 3 however, all the plants at that temperature were chlorotile. The plants wero harvested Ootober 2 , and final observations were taken. Chloresis seemed to be most severe in the 15 degree temperatures with some ohlorosis in evidenso in the 35 degree temperatures. The plants growing in red 11 ght in the 20 and 30 degree temperatures showed a el1 ght yellowing of the leaves, but all other plants were normal in color. From the evidence areilable at the time of harvest, ohlorosis appears to be nore influenoed by temperature variations than by 1ight quality or 1ight Intensity.

Besause of the marked differences in stem length, leaf size and yleld, these parte of the plant were measured separately. Then the leaves were separated from the stems, wahed eosording to the regular proeedure and dried in the oven. rable 3 shows the degree of ahloresle, the average terminal leaf measurement, the average length of stems and the averege dry weight of the plants. These date are shown graphleally In $P$ Igures 3 and 4. 
Table 3. Relationohips between soll temperature and 11 ght, and the growth and degree of ohlorosis of bean plents

\begin{tabular}{|c|c|c|c|c|c|}
\hline Treatinent & $\begin{array}{l}\text { Chloros is } \\
\text { rating }\end{array}$ & $\begin{array}{l}\text { Terminal } \\
\text { measure } \\
\text { length }\end{array}$ & $\begin{array}{l}\text { leap } \\
\text { mont } \\
\text { width }\end{array}$ & $\begin{array}{l}\text { Av. sten } \\
\text { length }\end{array}$ & $\begin{array}{l}\text { Av. Ary } \\
\text { welght }\end{array}$ \\
\hline & & $\left(\operatorname{man}_{0}\right)$ & $\left(\operatorname{man}_{0}\right)$ & $(\min )$. & (gms.) \\
\hline \multicolumn{6}{|l|}{$\operatorname{sel} 215^{\circ} \mathrm{C}$} \\
\hline Red 11ght & 2 & 71 & 46 & 182 & 0.775 \\
\hline B1ue 11ght & 2 & 52 & 36 & 162 & 0.389 \\
\hline Sunlsght & 8 & 52 & 33 & 119 & $\begin{array}{l}0.760 \\
1.982\end{array}$ \\
\hline \multicolumn{6}{|l|}{$\mathrm{Soll} 20^{\circ} \mathrm{C}$} \\
\hline Red 11 ght & 1 & 78 & 57 & 368 & 1.328 \\
\hline Blue 11ght & 0 & 68 & 48 & 272 & 1.063 \\
\hline Sund Ight & 0 & $\$ 1$ & 37 & 162 & $\begin{array}{l}1.748 \\
4.245\end{array}$ \\
\hline \multicolumn{6}{|l|}{$\operatorname{ses} 125^{\circ} \mathrm{c}$} \\
\hline Red 11 ght & 0 & 78 & 58 & 442 & 1.674 \\
\hline Dlue light & 0 & 68 & 47 & 265 & 0.939 \\
\hline Sunilght & 0 & 57 & 48 & 198 & $\begin{array}{l}2.427 \\
5.040\end{array}$ \\
\hline \multicolumn{6}{|l|}{ Sel1 $30^{\circ} \mathrm{C}$} \\
\hline $\begin{array}{l}\text { Bed 11ght } \\
\text { Blue light }\end{array}$ & $\frac{0.50=2}{0}$ & $\begin{array}{l}70 \\
64\end{array}$ & $\begin{array}{l}55 \\
47\end{array}$ & $\begin{array}{l}384 \\
261\end{array}$ & $\begin{array}{l}1.512 \\
0.064\end{array}$ \\
\hline Sunlight & 0 & 59 & 45 & 163 & $\begin{array}{l}2.250 \\
4.625\end{array}$ \\
\hline \multicolumn{6}{|l|}{$\operatorname{sol} 35^{\circ} \mathrm{C}$} \\
\hline Red light & 2 & 70 & 53 & 250 & 1.152 \\
\hline Blue light & 1. & 57 & 41 & 228 & 0.719 \\
\hline Sunlight & $0-1$ & 57 & 48 & 168 & $\begin{array}{l}2.038 \\
3.904\end{array}$ \\
\hline
\end{tabular}

- 0 Indlated no ohlorosis; 1. slight yellowing: 2. geveral yellowing of leaves: 3 . leaves bright yellow oolor; 4 . leaves bright yellow with oome nearosis. 


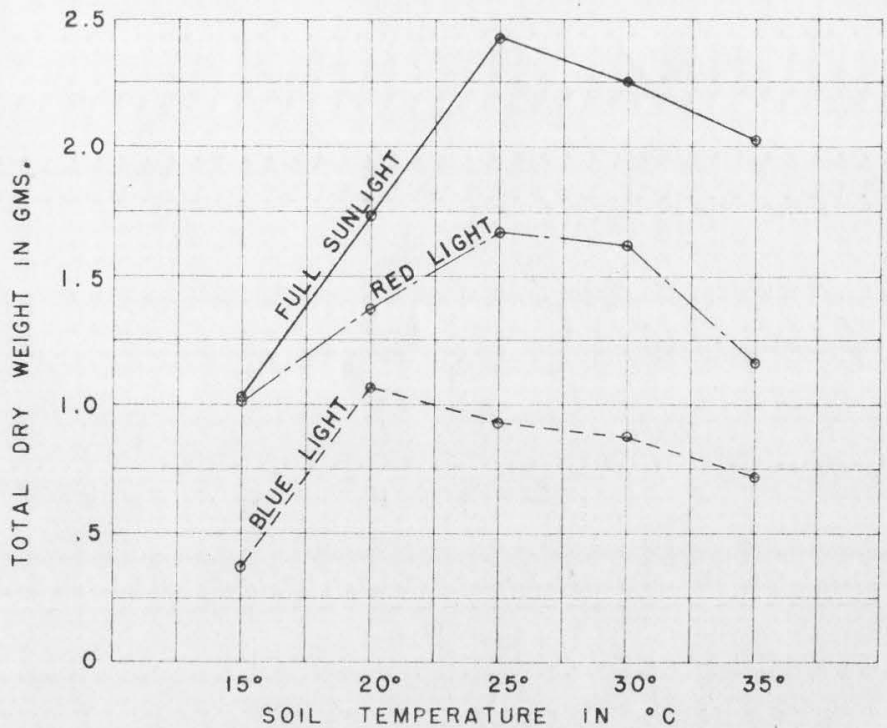

TOUTE 3. LIGHT AND SOIL TEMPERATURE IN RELATION TO THE TOTAL DRY WEIGHT OF BEAN TOPS

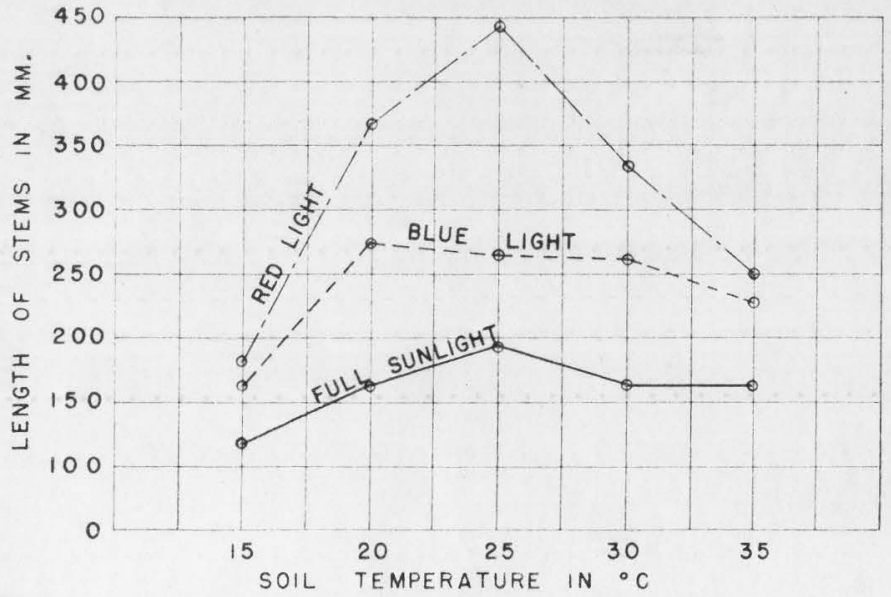

FIGURE THE RELATION BETWEEN LIGHT, SOIL TEMPERATURE AND AVERAGE LENGTH OF STEMS 
The greatest dry weight was produeed in full sunlight, followed by the red IIght and blue 11ght. The longest stents were produoed under red 11ght, blue 11 ght and $\mathrm{full}$ sunl1ght in that order. Red 11ght produced far larger lesves than elther the blue light or full sunllght. (Figure 5).

Table \& how the oalolum, potassium, phosphorus, manganese and total Iron sontent of the leaves for this experinent. The data do not show any consistent eerrelation with the degree of ehlorosis, but they do show several interesting trends. The phosphoras socumulatien in tho leaves variod 11ttle with 1ight treatments, but when the phesphorue content for 211 Ilght treatments was plotted agalnst temperature, a perabolis curve resulted with tho maximan st 25 cegrees. The aslolum oonteat, ea the other hand, showed no variation with elther 11ght or tempersture treatmeats. In general the potessiun aeoumulation was highest in the 15 degree plante and was sonsistently lower in the higher temperatures. As in Exporiment I, the manganese content of leaves was extrenely variable showing no consistent pattern with either 11ght or tenperature alfferenoes. The total iron content of the bean leaves was also variable with greater aifferenoes often oocurring between repliaktLens than between treatwents; howerer, the plants growing in the intermediate temperatures, 20 and 25 degrees, ghowed the least Iron aocumulation.

A complete stem and root analysis was not undertaken, but the total Iron oontent of a few sten seaples was determined to see if Iron had any tendency to aocuralate in the sten tissues. The analysis showed very 11ttle iron to be present in the stems of bean plants. 


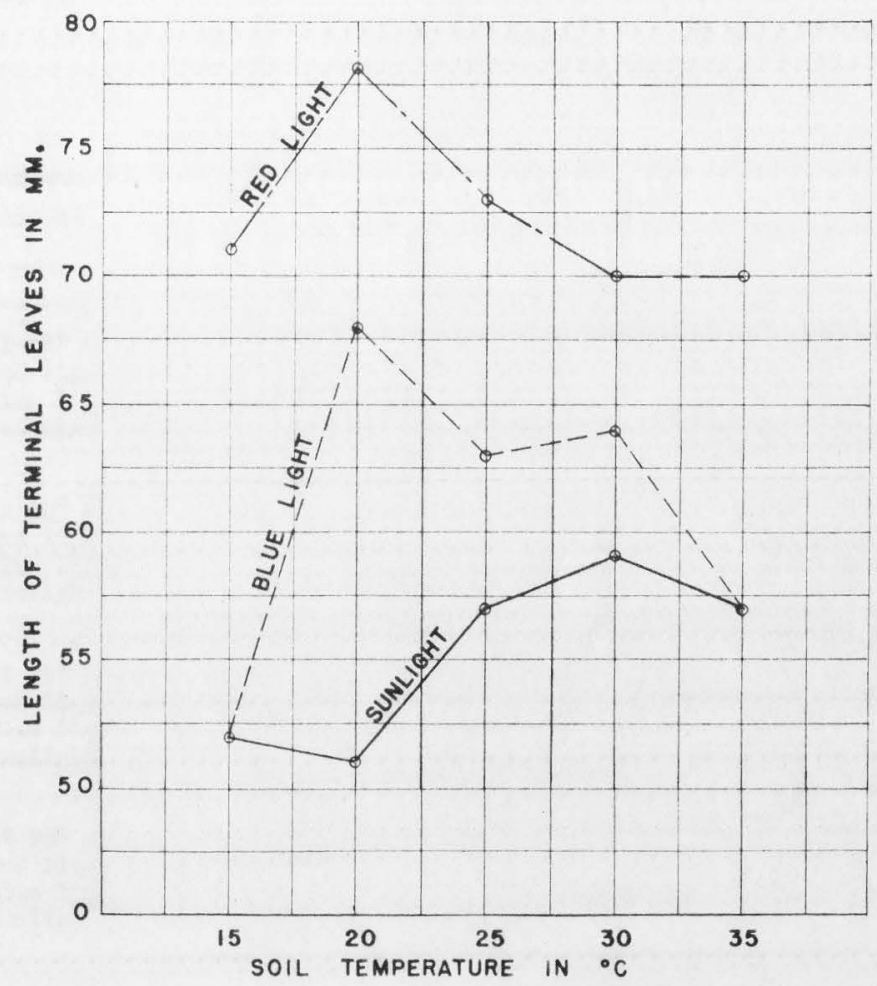

FIGURE 5. LIGHT AND SOIL TEMPERATURE IN RELATION TO LENGTH OF TERMINAL LEAVES OF BEANS 
Table 4. The Iron, vanganese, phosphorua, saloiun and potassium oontent of bean tops as related to light and soll temperature ocaditions

(analyses are roported on a dry welght basis)

\begin{tabular}{|c|c|c|c|c|c|c|}
\hline Treatuent & $\begin{array}{c}\text { Chlorosis } \\
\text { rating }\end{array}$ & $\begin{array}{l}\text { Av. } \\
\text { ge }\end{array}$ & Av. & Av. & $\begin{array}{c}\mathrm{Av} \\
\mathrm{Ca}\end{array}$ & $\begin{array}{c}\text { Av. } \\
\text { R }\end{array}$ \\
\hline & & $\mathrm{P} \cdot \mathrm{P} \cdot \mathrm{m}$ & $\mathrm{P}_{0} \mathrm{P}_{0} \mathrm{~m}_{0}$ & 8 & is & 2 \\
\hline \multicolumn{7}{|l|}{$\operatorname{sel} 115^{\circ} \mathrm{c}$} \\
\hline Red 11ght & 2 & 189 & $=-$ & .14 & $-\infty$ & $\infty$ \\
\hline Elue light & 1 & 204 & - & .20 & 2.82 & 4.78 \\
\hline Sunlight & 3 & $\frac{168}{562}$ & 224 & $\frac{.19}{.53}$ & 3.49 & 3.25 \\
\hline \multicolumn{7}{|l|}{$\operatorname{sen} 220^{\circ} \mathrm{C}$} \\
\hline Red 11.ght & 2 & 157 & 208 & .22 & 3.10 & 2.85 \\
\hline Blue light & 0 & 184 & 187 & .26 & 3.07 & 3.55 \\
\hline \multirow[t]{2}{*}{ sumi I ght } & 0 & 140 & 117 & .21 & 2.79 & 2.54 \\
\hline & & & & & & \\
\hline \multicolumn{7}{|l|}{$\operatorname{se} 1125^{\circ} \mathrm{C}$} \\
\hline Red 11.ght & 0 & 184 & 229 & .22 & 3.06 & 2.56 \\
\hline Blue 11 ght & 0 & 188 & 121 & .26 & 3.23 & 2.88 \\
\hline \multirow[t]{2}{*}{ Sundight } & 0 & 142 & 125 & .25 & 2.98 & 2.28 \\
\hline & & & & & & \\
\hline \multicolumn{7}{|l|}{$\operatorname{se1} 1130^{\circ} \mathrm{C}$} \\
\hline Red $11 \mathrm{ght}$ & 0.5 & 221 & 117 & .29 & 3.27 & 2.03 \\
\hline B1 ue 11ght & 0 & 305 & 158 & .22 & 2.76 & 2.40 \\
\hline Sunlight & 0 & $\frac{105}{70 I}$ & 204 & $\frac{.87}{.68}$ & 2.84 & 2.87 \\
\hline \multicolumn{7}{|l|}{ Sol1 $35^{\circ} \mathrm{C}$} \\
\hline Red 1Lght & 2 & 318 & 269 & .24 & 8.23 & 2.74 \\
\hline Blue 11 ght & 1 & 839 & 279 & .19 & 3.52 & 2.67 \\
\hline sunilight & .5 & 142 & 167 & .20 & 8.38 & 2.05 \\
\hline & & 785 & & .55 & & \\
\hline
\end{tabular}

0 Ind loates no ohlorosis; 1. Alight yellowing; 2. general yellowing of leaves: 3. leaves bright yellow color; 4. Leaves bright yellow with weme nearosis. 
Experiment III

A greonhouse experiment was next designed which would inolude 11ght, soll temperature and sol1 molsture variations with two repliostloxs. One add1tional oonerste tank was added to the genoral plan of Experiment I maicing total of 1 ix experimeatal temperaturs baths. The temperature varlables were reduged to three--17, 26, and 35 degrees

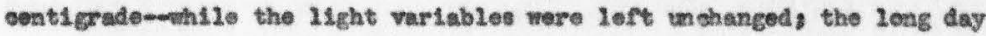
wnd shert day conditlone used In the origlnal design were retalned. The new variable, noisture, was introdueed in ex effort to deternine the relative importanoe of the varlous olimatlo factors in Induoing irca ahlorosis. Pour moleture levels were auperimposed on the temperature and 11 ght treatments. These molature levels Inolude Irrigation when the tension on the teneloneters resohed a marimum of 100,250 , and 600 oent1astere of water. The fourth nolsture level was pernitted to approalh the witing point before irrigetion was applied. This point wes found to be approximately 18,000 ohns rosistanee to eleotrical eurrent passage through a Dowyousos blook. The Bowyoucos bridge was used to measure this resistence.

Fresh soll fron the same sourse used in the first experiments was brought $1 \mathrm{n}$, trested as before, and potted Novenber 30 . The young seedlings were planted Desember 7. These plants were harvested prematurely beause of severe fumigation damage and a breakdown of the stirring apparatus used in maintaining sonstant teraperature.

New seedlings were plented on Desember 20 and observations were rosorded at weekly intervals. By January 15, it was evideat that IIght 
was the 1imting fastor in growth, but 11ttle differense sould be found in the easount of ahlorosis prodused by either a long day or a short day. Trees of yellowing were showing on the high moleture treatnonts in the I0w teaperature bath (17 degrees). The most signifleant soler differenoe, however, was osourring in the solls that were permitted to reash the wlting point before Irrigetion. N12 of the plants under this Ion noisture leve1, regardless of teaperature, wero ehowing a very derk, heelthy green oelor in the leaves.

By January 26, the d1fferenoe between the extrease iy dry treatmente was very, sigaiflant. The Intermedlate dry treatments, 600 contiraters of water, were a signifleantly 11 ghter color, but showed no siga of ohlorosis. The Intermediate wet and wet treatuents ahowed oonsiderable hilerosts in the 17 degree bathe and slight ohlerosis in the 25 degree baths. These differmeos in degree of nottilng seened to be the sane In both the long and short day light treatwente, but growth rates wers great1y Inoreased by the extra 111uaination of the long day.

On Debruary 5, the plents were removed fron the tenke and the fIns observatlons resorded. Sone ohlorosis was apgarent in all the 17 degree treatuente expept these in whioh the plants were subjeated to extrene drought. The plants under this low molsture oondition had a dark green oelor. The ast extrene yellowdng oocured In the low $11 \mathrm{ght}$, high moleture treatmonts. Tis observation would at first glance Indieate that ahlorosis is inorossed by reducs light as well as by high nolsture and low tesperature. However, thle observation does not hold for the other temperatures, and a better explanation would sean to be that the plants. 
beause of the1 $r$ reduoed grovth, had a lower transpiration rate and thus remained wet for longer periods than the plants growing under the long dag.

The degree of ohlorosis seemed to be most severo under high molsture and low teraperature with some ohlorosis ovourring under high molsture and high temperature. Only traces of ahlorosis were evident in any treatment undor the 25 degree torgeratures. Tlo plents beane ohlerotic under oonditions of extremely low molsture under any light or temperature treatnent, but the plants subjeoted to molsture tensions of 600 on. of water were a signiflosutly 11ghter green. The 11ghter color notioed in these plants, however, did not show any symptons of 1Imo-indused ohlorosis.

After the final observations were reoorded, the plants wore harvested sooording to the prosedure usod in Bxperlment II. Table 5 shows the date for the dogree of shlerosis, longth of stems and totel dry weight of plant tops for the oxperimontal sonditions. The yleld data are shown graphieally in P1gures 6 and 7. From tho ourves in PIgure 6. It is evident that the greatest sten elongation oosurred under the long day and at a soll temperature of 25 degrees, followed by the long day and 35 degree soll temporature. In general the greatest elongetion oosurred at the Internediate molsture level, 250 on, of water, and the least elongation of stems was produced by the extremely low noisture

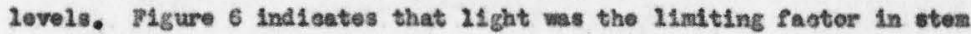
elengation under the short day 11ght treatment.

The dry weight ourve, Plgurs 7, followed the same trend as the ourve for stem length with the exception that under the long day treat- 


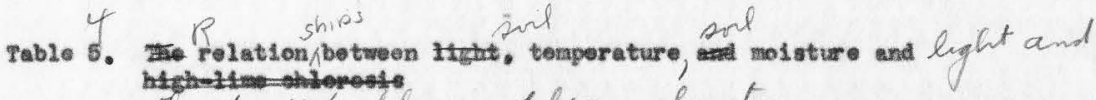

\begin{tabular}{|c|c|c|c|c|}
\hline $\begin{array}{l}\text { tax. mol sture } \\
\text { tensien }\end{array}$ & $\begin{array}{l}\text { Leht } \\
\text { aond ltions }\end{array}$ & $\begin{array}{c}\text { Chlorosts } \\
\text { rating }\end{array}$ & $\begin{array}{l}\text { Av. sten } \\
\text { Iongth }\end{array}$ & Av. $\frac{\text { dry }}{\text { weight }}$ \\
\hline an, of $\mathrm{Beb}$ & & & amb. & gine. \\
\hline \multicolumn{5}{|l|}{$501217^{\circ} \mathrm{C}$} \\
\hline 100 & long day & 1.00 & 98 & 1.805 \\
\hline 250 & $=$ & 0.50 & 78 & 1.808 \\
\hline 600 & n $\quad$ n & 0.50 & 76 & 1.582 \\
\hline walting point & siben " & dark green & 42 & 0.980 \\
\hline 100 & short day & 3.50 & 52 & 0.985 \\
\hline 250 & * & 0.76 & 31 & 0.526 \\
\hline 600 & * & 1.00 & 32 & 0.904 \\
\hline wiltising point & * $\quad *$ & dark groen & 35 & 0.688 \\
\hline \multicolumn{5}{|l|}{$\operatorname{se1} 25^{\circ} \mathrm{c}$} \\
\hline 100 & long day & 0.75 & 126 & 2.637 \\
\hline 250 & " & 1.00 & 159 & 3.471 \\
\hline 600 & " & 0.00 & 208 & 1.780 \\
\hline w11ting point & " & dark green & 78 & 1.098 \\
\hline 100 & short dey & 0.75 & $\$ 5$ & 1.242 \\
\hline 250 & " n & 0.25 & 48 & 0.838 \\
\hline 600 & " & 0.60 & 44 & 0.544 \\
\hline wilting point & " & dark green & 34 & 0.630 \\
\hline \multicolumn{5}{|l|}{$\operatorname{sel1} 33^{\circ} \mathrm{C}$} \\
\hline 100 & long day & 1.60 & 108 & 2.805 \\
\hline 250 & $"$ & 0.25 & 129 & 1.961 \\
\hline 600 & " & 0.00 & 78 & 0.754 \\
\hline wd1ting point & " & derts green & 55 & 0.528 \\
\hline 100 & $\underset{n}{\text { short day }}$ & 1.60 & 54 & 3.190 \\
\hline $\begin{array}{l}250 \\
600\end{array}$ & n & $\begin{array}{l}1.50 \\
0.50\end{array}$ & 52 & 0.845 \\
\hline witing point & n & dark green & 30 & 0.410 \\
\hline
\end{tabular}

* O Indiaateg no chlorosis; 1. alight yellowimgs 2. ganeral yellowIng of leaves; 3. Leaves bright yellow solor: 4. leaves bright yellow with some nearesis. 


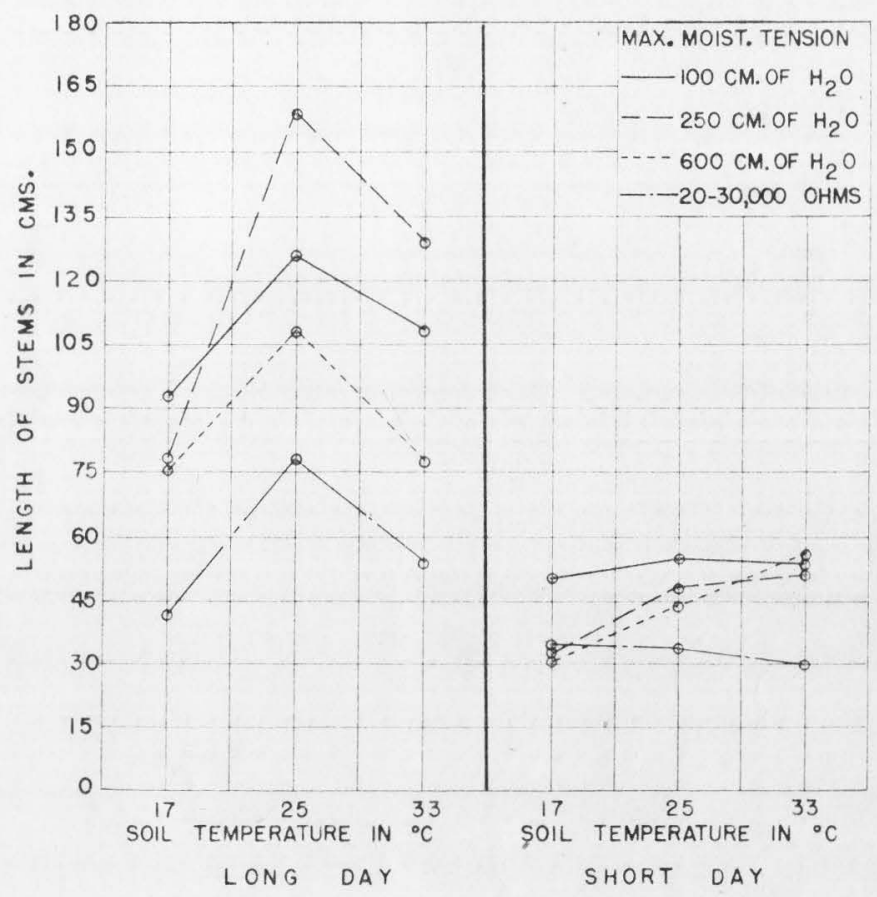

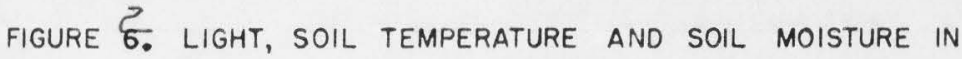
RELATION TO THE LENGTH OF STEMS OF BEAN PLANTS 


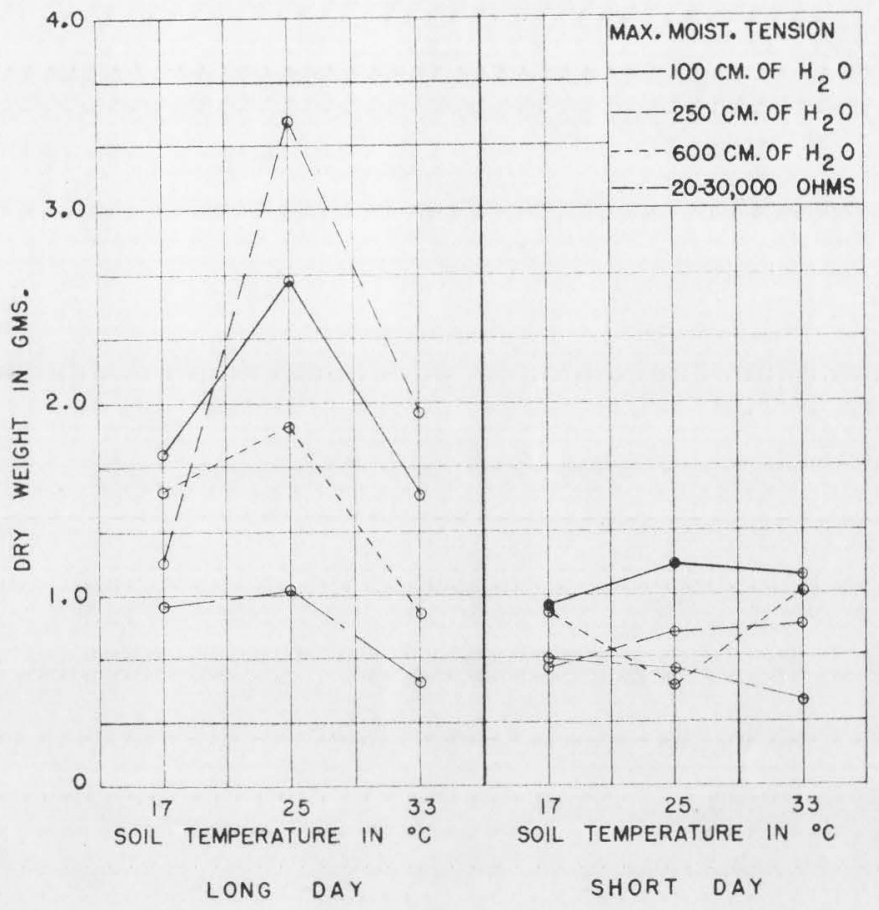

FIGURE 7. LIGHT, SOIL TEMPERATURE AND SOIL MOISTURE IN RELATION TO THE TOTAL DRY WEIGHT OF BEAN TOPS 
ment, more total dry welght was produigd under the 17 degree soll temperature than under the 35 degree so12 temperature.

The leaf samples were ground and digested assording to the prosedure desoribed on page 12. The samples were then analyzed ohenaloally for oalolum, potassium, total 1ron, phosphorus and nanganose. Those data are reported in table 6.

The ealofun sontent of the leaves remained virtually constant regardless of temperature or light variations. This sowe pattern was obeerred In Experiments I and II. Potassiun as before, was extrencly variable with variatione between replleations often greater then variatless between treativents. As in the other expariments, there was no Indieatiok of a low saloium to potessium ratio. The phosphorus sontent of the bean leaves followed the sams parabolio ourve deseribed in Bxperiment II Ind loat1ng that phosphorus is affeoted more by temperature ohanges than by molsture or 11 ght difforensen. In all exporimonts, the maximum phoaphorus sosumulation odourred at 25 degrees. The total Iron sontent of the bean leaves varled oonollerably with both teagerature and nolsture but 11ttle with 1ight oonditions. In general the total Iron content was ignifleantly greater In the low temperature, 17 dogreos, for all variations of Light and misture. In the long-dey treatment the alnimum Iron soevmulation tended to oesur at the 25 degree temperature leve1. but in the short-day treatment, the minimus iron accumulation ooourred at the highest tomperature. As in the other experinents, the manganese content was extremely variable, but the lowest manganese soneentration seemed to oesur at the 25 degree sonperature for all treatnents. 
Table 6. The poteselum, oaloium, phosphorus, iron and mazanese oontent of besn tops related to $11 \mathrm{ght}$, temperature and sol1 nolsture condition

(analyses are regorted on a dry whe basis)

\begin{tabular}{|c|c|c|c|c|c|c|c|}
\hline $\begin{array}{l}\text { tex } \\
\text { tension }\end{array}$ & $\begin{array}{l}\text { Light } \\
\text { nonditions }\end{array}$ & $\begin{array}{c}\text { Chlorosis } \\
\text { rating }\end{array}$ & $\stackrel{A V}{R}$ & $\begin{array}{l}\mathrm{Av} . \\
\mathrm{Ca}\end{array}$ & $\frac{\mathrm{AV}}{p}$ & $\begin{array}{l}\text { Av. } \\
\text { Pe }\end{array}$ & $\begin{array}{l}A \nabla_{0} \\
\mathrm{Na}_{0}\end{array}$ \\
\hline om. of Eี200 & & & $\$$ & $x$ & 1 & P.P.P. & $\mathrm{P} \cdot \mathrm{P} \cdot \mathrm{nin}$ \\
\hline \multicolumn{8}{|l|}{$\operatorname{sed1} 170 \mathrm{c}$} \\
\hline 100 & long day & 1.00 & 6.37 & 2.89 & .22 & $15 \%$ & 229 \\
\hline 250 & " & 0.50 & 6.73 & 2.70 & .20 & 240 & 92 \\
\hline 600 & " & 0.50 & 4.15 & 2.42 & .19 & 176 & 117 \\
\hline wilting pt. & * & darik gre. & 4.29 & 2.56 & .21 & 208 & 204 \\
\hline 100 & short day & 8.50 & 5.05 & 2.03 & .20 & 238 & 217 \\
\hline 250 & " & 0.78 & 6.61 & 2.37 & .28 & 265 & 129 \\
\hline 600 & n & 1.00 & 4.78 & 2.20 & .26 & 198 & 48 \\
\hline wLttng gt. & * & dark er. & 6.82 & 2.16 & .27 & 202 & 67 \\
\hline \multicolumn{8}{|l|}{$\operatorname{ses} 125^{\circ} \mathrm{C}$} \\
\hline 100 & lone day & 0.75 & 5.37 & 2.25 & .46 & 140 & 92 \\
\hline 250 & & 1.00 & 5.27 & 2.08 & .36 & 245 & 67 \\
\hline 600 & $*$ & 0.00 & 5.87 & 2.27 & .83 & 168 & 79 \\
\hline witing pt. & $n$ & dark er. & 6.00 & 2.42 & .32 & 109 & 58 \\
\hline 100 & short day & 0.75 & 4.90 & 2.20 & .37 & 158 & 48 \\
\hline 250 & " & 0.28 & 6.29 & 2.37 & .32 & 198 & 45 \\
\hline 600 & * & 0.50 & 6.15 & 2.44 & .32 & 175 & 56 \\
\hline w11tsng pt. & $n$ & dark $e^{2}$ & 5.16 & 2.22 & .28 & 170 & 38 \\
\hline \multicolumn{8}{|l|}{$8011330 \mathrm{C}$} \\
\hline 100 & long dey & 1.50 & 5.68 & 2.52 & .28 & 168 & 107 \\
\hline 250 & 7 & 0.26 & 5.56 & 2.81 & .31 & 135 & 67 \\
\hline 600 & n & 0.00 & 5.73 & 2.66 & .28 & 165 & 45 \\
\hline w11ting pt. & * & dark SF. & 6.68 & 3.12 & .25 & 170 & 98 \\
\hline 100 & short day & 1.50 & 5.07 & 2.73 & .31 & 246 & 75 \\
\hline 280 & * & 1.50 & 6.39 & 3.02 & .27 & 120 & 123 \\
\hline 600 & 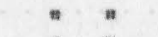 & 0.50 & 4.44 & 2.73 & 28 & 246 & 95 \\
\hline wilting pt. & $"$ & daric er. & 6.63 & 2.29 & .31 & 87 & 138 \\
\hline
\end{tabular}

- 0 indioutes an ohlorosis \& 1. elight yellewings 2. goneral yallowing of leaves 5 . Leaves bright yellow oolor: 4. Leaves bright yellew with some nearosis. 


\section{Experinent IV}

Experiment IV was designed primarily to verify the resulte obtained in Experiment III. A seoond purpose of the experisent was to try to deternine whether the great difrerenoe in oolor between the extreme Ary and the intermediate dry treatments ms due to a nitrogon derlalengy or to other sauses.

The experinental design wa modified to inelude tenolonoters in the extreme ary treatants. The purpose of these additional tension moters was to give a nore aosurate molsture reading whon the dry pots were Arrigated. This is advantagoous begause the Bourousos blodks are not very affeotive at high-abisture levels. The temperatures were nodified alighty 1r an attonpt to exaggerate the ohlorsals symptons. The temperatures for this experimont sonsigted of 15,25 and 34 degroes sentigrade. The sarae sol1 used in Experinent III was used in this experiasent, and the pots were undisturbod exsept for a 600 pound per are addition of Jranon $(42-0-0)$ fort121zer. Baoh soll was given the same nolsture and temperature treatwent whioh it reoelval in the previous experinent, but the pots were again randowised vithin temperature baths.

Great Northern bean seedlings wro planted on Naroh 2 and were given soveral dsys to become established. Temporature coatrols wore

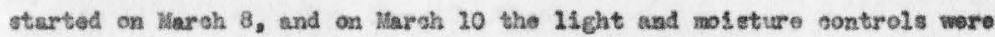
ostablished. The delay in starting the solature aoatrols was used to permit the young plants in the extromely dry treatuonts to booone better establ1ehed bofore subjoeting then to extrease drought. 
Frow the start, growth was hindered by a reot rot disease whieh had beeone established in the soll of some of the pots. Transplanting new plexts Inte these diseased sells was not auocessful.

The observations teken April 3 howed a moderate ahlorosi in in the 15 ciegree-h1gh-roo isture (200 ah,) treatuent. Plants in the dry soll held at 15 degrees were s dark green soler. Rants under the 16 degree high-moleture, hort-day trestment showed extreme yellowing, with a few leaves appearlng nearly white. The plants growing under the 25 and 85 degree temperatures all howed normal grees growth. There was no Indioation of the 1Ighter green oolor not1 aed In the 600 sentimeters of water tension plants in the previoue experiment, Indleating that perhapk the oolor differenee had been due to a lack of altrogen. Growth was extremaly reriable besause of the root rot disease, however. growth of unaffested plants seened to vary but little with molsture.

On April 12, the sonditicas renained unohanged at the 15 degroe temperature level under the leng-days but under the short-day, the highmolsture treatment showed igne of resevery. The lower, older leaves retained the severe ohlerosis syiagtoss, but the younger, upper leaves appeared normal in selor. The hlgh-molsture treatment under the leagday showed slight ohloresis syaptons, but al2 plants under both lengths of day were nermal in color.

The plants growing under the short-day 11ght treatment were approachIng aturity at fanter rate than those growing under the added 11 ght. The rate of growth appeared greatent at 25 degrees for all 11 ght oond1tions, follewed by the 25 degree tenperature under the ahert-day. 
On Apr11 16 final obserwations were resorded, and the plants were harrssted. On this aste all of the thlorotio plants showed elther somplete resovery or defindte igns of Improvenont on the young leaves. The growth was extremely rariable, but in general the Iemgest stems oseurred under the wetter treatments in the 25 degree temperature. The resulte fron thl s experiment indieated that som feotor other than temperature or molsture was osusing the improvement of the ahlorotis plants. The anost probeble explanation for the Inprovement would seex to be either an increased 1ight Intensity or an inereased alr temperature. 
The experinents show that the sombination of a high soll molsture Level and a low soll temperature are the efinftio sonditions mot sonduoive to the oosurrense of $11 \mathrm{mo}$ ohlorosis. Holther Quality, intensity and duration of light appear to be of heser ignifleance in the oseur-

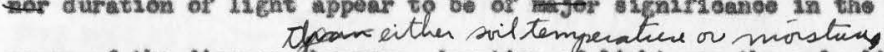
renoe of the disease, however, duration of 11 ght was the only light oondition tested sufflelently to draw definito conslusions. The study of 1ight intensity was IImited to one experiment, and sinoe that experiment was oondusted rather late in the summer sesson, it is doubtful that the effests of rull sumer light intensity were obtained. TH Hat guallty have a quatu influme on plant stuedure than in

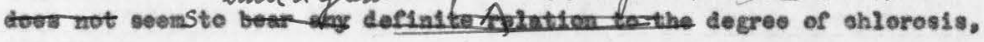
but 14 toe - have a s igniflant effeot on the stragture of the plant. II gh soll molsture levele seen to be the most signifleant factor In 11 an ehlorosis, but low soll temperatures also indues the sondition, The data are in agreerent with the fleld observations of Reuther and Crawford $(19,20)$. Thorne (24), 0110 and Carrero (6), and Burgess and Pohlman (2).

The results tend to contradlet the findings of Ingalls and Shive (10), Wanis frif, Gerioke (5), and Hopicins (9). These investigators aite evidenee to show that $14 \mathrm{ght}$ intensity may be the most slgnifioant of the olimat1s fastors. Gerioke, however, stated that the greater occurrense of ohlorosis in plants growing under high light intensity nay be gased by the inoreased rate of growth under those sonditions. Gerleke. therefore, belleved that the plants exposed to high IIght Intensity outgrew their Iron supply fanter than the plants growing under 
sheded sonditions, Hoplcins' work was done in Forto Riso where ohlerom is seerss to be aused by high ratlo of anganese to iron in the so11. There 1s 11 ttle evidenee to show that the iron-manganese ratio is a ause of shlerosis in Dtah. Ingalls and Shive consluded fron their data that the iron requirement for plants varies with the light interalty. They were working with sulture solutlons, however, and wero probably

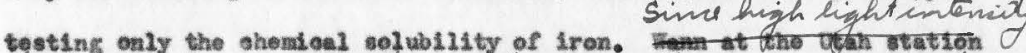
duning simme monthe is als wanally accompanied

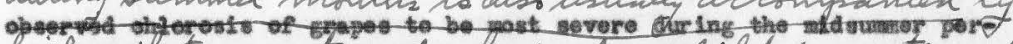

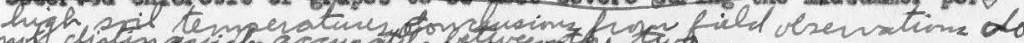

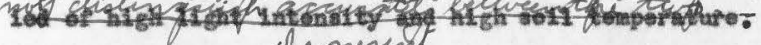
the presch

The results of thof experiments indigate that much of the 13meohlorosis in the Irrigated reglone of the west sould be alleviated by the proper uee of Irrigation water. In some poorly drained seotions affected by the disease, dralnage, If esenond anly foasible, should help by renoving excess water in the apring of the your. This removal of water would, In turn, Improve the situatien by peralttins a faster Insrease in soll temperature. The most satisfaotory irrigntion practise seems to be one uelng heavy irrigations with modium-long periods between irrigations.

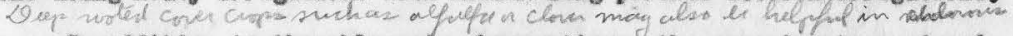

In addition to the ohloresis oberrvtions, the experinents produeed sone interesting growth relationships. These results on yleld and elongation of plents verify the observations of several plant physielegiste as mumarised by MIIer (16). N11er states that in general the

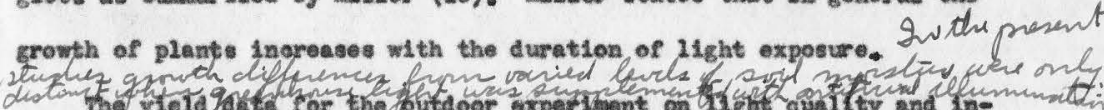

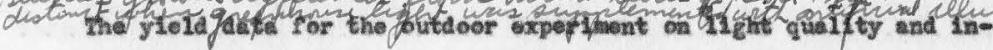
tensity alse follow the pattern of sarlier Investigations. Fron Neyer and Anderson's (15) disoussion of 11 glrt quality and 1ntensity, It sppears that the outdoor experinentel results follew the general pattern of 11 ght Intenslty nore slosely than they do 1ight quality. Meyer and Anderson 
sumarize sereral reports whioh indieate that the tetsi dry weight and thiokness of stem and leaf, all Insrease with an inorease in IIght Intensity. Haximum height of plants and maximum leaf area, however, oseur st IIght intensitie oonsiderably below those of full sumner sum11 ght.

The sontradistery reports in the IIterature as well as the Inoonsistenoles in the present series of experiments ind I oate the somplexity of the problem. Soll taken from shlorotie locations often grow normal plants when mixed and plased In pots. On several osnasions, the same pot was found to sontain both normal and ohlorotio plants. Furthermore. the ohendoal analyals showod no oorrelation between the decree of chlorosis and the content firms in plants that che

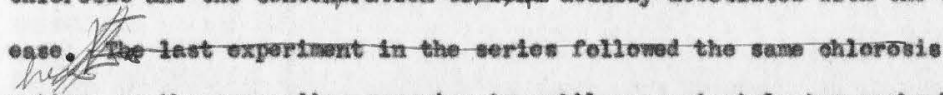
pattern-as the prevesting experiments unt11 spproxinately two weeks - before the harvest; then for no apparent reason the plants began showing Stges of pasowary. Sines-the soli moteture and temperature levels renedned oonstant throughout the experinent, the inproveanent must havebeen-due to seme inoentrolled fator-perhaps alr temperature or basterLad sotiotty-

The dis arepancy between the fIrst experiment and the later studies ean perhags be explained. In the firet experinent, ohlorosis was most severe under conditions of high temperature than under low soll temperatures. There was a tendenoy for the soll at the $\mathrm{hlgh}$ temperature to dry out rapidly at the ourface. Since no means for measuring the moisture content was Included in the experinental design, these pots were in cons asses over-1rrigated and part1aliy vatorlegged at the bottos. In the 
later experinents molsture was oontrolled through the use of tensioweters and Beuyouves bloaks. Under these sontrolled oond1tions, ohlorosis was mare severe at the $10 \mathrm{w}$ soll temperatures than at the high.

In the ovent edditional experinents sindlar to those roported are conduated, several cugsestons may prove helprul. Sinee the moveribnt of the soll from it or Iginal losation aeens to roduse the tendenoy of the all to produae ohlorotis plants, It might be profltable to sanplo the seil In horizons and to Inolude the stune general layering of soll In the pots that was present in the Pleld. Crowing preilminary erop In the pots may halp the soll regaln 1 ts or 1 ginal strueture.

An outdoer experiment Involving the lntensity of 12ght should be sondurted using fewer temperatures and more repls cacions. An attenpt should be made to reduse the varlability of 11 ght Intenelty by using heesesloth shades over part of the plants exposed to full sunlight. Varlous nolsture levels should also be inoluded in the design. 


\section{concLus ION}

A high-soll molsture level together with low-soll temperature Is the sondition nost sonduelve to the developrent of high-line ahlorosis. Feither guality. Intensity nor duration of 11 ght seem of major importanes In the ooourrente of the dieesse. The order of insportanee of the indirlaul alimatio faotors appears to bes (1) a high-soll molsture level. (2) a low-soll temperature, (3) a high-soll temperature, (4) 11ght. 
1. The effect of Climatio sonditions on thigh-1ime ohlorosis is an agpeot of the problem whloh has reesived 11.t10 attention. The investigation was deeigned to otudy the importanoe of the elimetie faclons $y$ sonditions 1ight, soll tenporature and soll molsture on a lineIndused ohlorosis.

2. Bean plants wore grown in high-11we soll placed in 15 inoh-doep tere pots. The pots wero suspended in water baths at various oon otant temperatures ranglng fros 15 to 35 degrees cent1 grado. Light varlatioas uvod insluded: full sumer sullght, full surmar aunlight through red and blae plasties of knewn light tranemission values, normal winter day in the greenhouse, and normel winter dey in the greashouee plus 7 hours of artifletel 111 unination. Hoisture Ievels were eontrolled through the use of tenslonsters and Bouyousos bloake. Moleture variation inoluded Irrigation at maximum soll tensions of 75, 100, 250, $600-700$ sent1ngter of water, and near the w11ting polnt. Resords ware made of the degree of ohlorosis of plants at regular intarvals. The yleld of plants and their mineral content was determined.

3. The results Indloäte that a high-rolsture level together w1th 200 so12 temporature Is the sonditien noet oonduoive to the developanat of high-11me ohlorosis. Haither guality. Ixtendty nor duration of IIght seom of major Inportance in the oocurzenoe of the divease. The order of Importance of the individual ollmatie fuetor sppears to be (1) a high coll molsture level, (2) a low soll terperature. (s) high soll temporature, (4) 11ght. 
5. The data indioate that auch of the 11me-ghlorosis in the 1rrigated sertions of the west sould be alleviated by the proper use of Irrigat1on water. 


\section{LTTERATURE CTRED}

1. Allen, R. J. L. 1940 The estimation of phosphorus. Bioahem. Jour. $34,858-865$.

2. Burgees, P. S. and Pohlman, G. O, 1928 citrus ohlorosis as affected by irrigation and rertilizer treatments. Ar 12. Agr. Exp. Sta. BuI. 124: 183-232.

3. Chapman, E. D. 1939 Absorption of Iron froil Pinely ground nagnitito by eltrus seedlinge. Soll 801 . 48: 309-315.

4. Cook, J. W. 2941 Rapid method for determination of manganese in feeds. Indus, and Ingin. Chem, (Anal. Rd.). 13: 48-50.

5. Geriake, \%. F. 1925 Bffeet of 11ght on availability of iron to wheat plants in water oultures. Bot. Gas. 79: 106-108.

6. G1le, P. L. and Carrero, J. O. 2920 Causes of 1 ine-ind ueed ahloresis and avallability of iron In the soll. Jour. Agr. Res. $20: 33-62$.

7. Hass, A. R. C. 1942 Lime-indused ohlorosis of eltrus in relation to soli faetors. Plant Physlol. 17: 27-51.

8. Hofler, $\mathrm{K}, 1944$ Abeut 11me-ghlorosis and galoious in 1941 and 1. 8. Ilglas bioohend eal experiments, Phytopath Ztsohr. 14: 192-205. (translated by Marle S. Kollsoh).

9. Hopicins, B. F., Pagan, V.. and S1Iva, F. J. R. 2944 tron and manganese in relation to plant growth and its Importance in Puerto R100. Jour. Agr. UnIv, Puarto R100. 28: 48-101.

10. Ingalls, R, A. and Shive, J. W. 1931 Relation of hydrogen loa conoentration of tissue fludds to the distribution of 1 ron in plants. Plant Physiol, 6: 103-125.

11. Jenes, L. H. 1938 Relation of soll temperature to ohlorosis of gardenit. Jour. Agr. Res, 57, 611-621.

12. Rliman, S. 1938 Importanee of forrous 1 ron in plants and solls. Proo. Soll Sel. Sos. Amer. 2: 385-392.

13. Linder, R. C. and Harley, C. P. 1944 Vitrient interrelations in 11me-Induoed ahlorosis. Plant Physiel. 19: 420-439.

14. Loelwing. W. F. $2928 \mathrm{Calolum}$, potassium and iron balanee in sertain arop plants in rolation to their metabollem. Plant Physiol. 3, 261-275. 
15. Noyer, B. S. and Anderson, D. B. 1932 Plant physlology. D. Van Westrand Compery, Hew York.

16. M1ler, E."C. 1938 Mant physiolog. 2nd. Ed. Modraw-I1111 Book Company, New York.

17. Oserkowiki, J. 2985 quantitative relation between ahlorophy 21 and Iron in green and ohlorotis pear trees. Mant Physlol.

8. $440-468$.

28. Reitemeir, 8. F. 1943 Send-miaroanalysis of saline soil solutions. Indus, and Engin, Chom, 25, 303.

19. Reuther, 筑, and Crawford, C. L. 1946 Erfoet of oertain sol1 and Irrigation treatmente on oltrus ahlorosis in aleareoue solls plant responses. So11 S01, 62, $477-4$ 21.

20. Reuther, $w_{\text {. }}$ and Crawford, $C_{\text {. L. }} 1947$ Effeet of oertain soll and irrigation treatmonts on altrus ahlocosis in a oaloareous soll. so11 atmesphere studies. Sell Sa. 63: 227-240.

21. Siderss, C. P. and Young, H. Y, 1944 Brfeots of Iron on ohlorophyli ous pigments, ssoorbio sold, coldity, and carbohydrates of

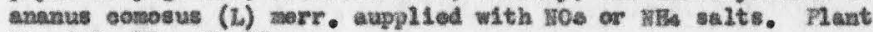
Fhys101. 10, 52-75.

22. Smith, C. F. and Rlehter, F. P. 1944. Phenanthroline and subst1tuted phenanthroline indieaters. The $G$. Frederiak Salth Cheml oal Congany, Coluabus, Ohis.

23. Soners, I. I. and ShIve, J. W. 1942 The iron-manganese relation In plant motaboliem, Mant Fysiol, 17, 538-601.

24. Thorne, D. 1948 Y Yelds of peach orohards materially inoreased by proper soil managonent praotiees. Farm and Home Sol, 908.

25. Thorne, D. 笛, and Willace, A. 2944 Some fuotors affeoting ahloros1s on high-11mo so11s; ferrous and ferris $15 \mathrm{~cm}$. Soll Sol, 57, 299-312.

26. Walleve. T. 2928 Inverelgâtions on ahlorosis of fruit trees 3 oonposition of leaves, bark, and wood of eurrunt season's shoots in eases of IIme-Indused ohlorosis. Jour. Pom. Hort. So1. 7,172-183.

27. Nann, F. B. 2942 Control of olderosis in grapes. Wtah Agr. Exp. Sta. Bus. 299: 1-27.

28. Mitney, R. S. and Gardner, R, 2943 The affeot of garbon dioxide on goll reastion. Soli 8 al. 65 : 127-141.

29. W1111s, to 0.1932 The offeat of 11 ming solis on the availability of manganese and Iron. Jour. Amor. S00. Agron. 24: 116-726. 